\title{
Policijas zinātnes attīstība Eiropā
}

\author{
Aleksandrs Matvejevs \\ Daugavpils Universitāte, Sociālo zinātṇu fakultāte, \\ Tiesību katedra, Latvija
}

\section{Kopsavilkums}

Policijas zinātnes attīstības perspektīvas Eiropā un ar to saistītie pētījumu rezultāti atspoguloti publicētajos materiālos. Pētījumos ir atspoguḷoti dažādi viedokḷi, tomēr vairākums aizstāv uzskatu, ka Eiropā jāattīsta policijas zinātne kā atsevišḳa zinātnes nozare.

Pētỉjuma nolūks ir aplūkot policijas zinātnes attīstības perspektīvas Eiropā, un šì publikācija varētu kalpot par sākumu zinātniskām debatēm par policijas zinātnes jautājumu.

Policijas zinātne nākotnē varētu būt integrācijas instruments gan nacionālā, gan starptautiskā līmenī. Tās attīstības perspektīvas Eiropā ir atkarīgas gan no akadēmisko, gan policijas aprindu aktivitātēm.

Atslēgvārdi: policija, policijas zinātne, policijas darbība.

\section{levads}

Pētījumi policijas tiesībās, kriminologiijā, kriminālistikā utt. ir prezentējuši virkni teorētisko un empīrisko apkopojumu. Veiktajos pētijumos tiek izmantota starpdisciplināra pieeja, un vēl joprojām nav attīstìta policijas zinātne.

Raksta ideja ir ieskicēt policijas zinātnes attīstības perspektīvas Eiropā un izvērst diskusiju par iespēju attīstīt policijas zinātni Latvijā.

Latvijā 2001. gadā ar Zinātnes padomes lēmumu policijas tiesības tika iekḷautas juridiskās zinātnes apakšnozares klasifikācijā. Policijas tiesības ir juridisko zinātṇu apakšnozare, kura teorētiski un empīriski pēta policiju kā institūciju, tās darbības tiesiskumu, organizāciju, uzdevumus un lomu sociālajā struktūrā, tās darba stilu, efektivitāti, kā arī izpausmes veidu un attieksmi pret sabiedrību. 


\section{Pētijuma mērḳis un uzdevumi}

Pētījuma mērḳis ir izpētìt policijas zinātnes attīstības perspektīvas Eiropā. Izvirzītais mērḳis tika sasniegts, realizējot šādus pētỉjuma uzdevumus: apskatot policijas zinātnes vēsturi, policijas zinātnes aktuālos jautājumus, analizējot policijas izglītības un apmācības problēmas Eiropā.

Pētījuma zinātniskā novitāte ir saistīta ar to, ka pētỉjumā mēǵināts izsekot policijas zinātnes attīstības perspektīvām Eiropā.

Apkopojot izpētìto, jāsecina, ka var izveidoties konflikts starp teoriju un praksi, ja netiks veikti teorētiskie un empīriskie pētỉjumi par policijas jomu, lai nodrošinātu efektīvu policijas darbību.

\section{Policijas zinātnes vēsturiskā attīstība}

Lai gan terminam "policijas zinātne" mūsdienu sociālajās zinātnēs nav vispārpieñemtas nozìmes un citi to apzīmē kā policijas peetỉjumus vai zinātniskos pètījumus saistībā ar policiju, tam tomēr ir senas tradīcijas.

18. gadsimta sākumā bija pirmais mēgeinājums zinātniski analizēt policijas darbības jomu, kurā ietilpa visa iekšējā valsts pārvalde, ieskaitot justīciju un finanses. Francijā, aizsteidzoties priekšā citām valstīm, sāka veidoties zinātne par policiju.

18. gadsimtā policijas zinātne bija valdības zinātne, l̦oti plašs jēdziens, kas ietvēra gandrīz visus valdības uzdevumus. Līdzīgi kā franču vārds police, tā arī vācu polizei apzīmēja veselu virkni valdības aktivitāšu ilgi pirms laika, kad izveidojās policijas spēki, kuru uzdevums bija tās îstenot - tas notika galvenokārt 19. gadsimtā. [3]

Policijas zinātne kḷuva par akadēmisku disciplīnu dažās Eiropas valstīs 19. gs., un tā tika iekḷauta universitāšu programmās. Pat tajās valstīs, kur nelietoja terminu "policijas zinātne", tika izveidotas līdzīgas universitātes disciplīnas, ko apzīmēja ar terminiem "politiskā zinātne" vai pat "militārās zinātnes".

20. gs. termins "policijas zinātne" sāka izzust, to aizstāja ar kriminologijas un kriminālistikas nozīmi.

Kopš pagājušā gadsimta 70. gadiem lielākajā daḷā Eiropas valstu parādās empīriskie pētījumi, kas notiek divējādi: pētījumus veic akadēmiskais personāls par policijas darbību un pētījumi, ko ierosina pati policija. Pētījumi Eiropā saistīti ar policijas un tās aktivitāšu vēsturisko pirmsākumu un attīstības izpēti. Lielākajā dạ̦ā Eiropas valstu policijas funkcijas pakāpeniski tiek atdalītas no militārā spēka lietošanas, un valdnieku privātās intereses tiek balstītas uz tiesību aktiem, lai nodrošinātu taisnīgumu un tiesu varu un kalpotu visas sabiedrības interesēm. Citi pētỉjumu temati, sekojot vēsturiskajai perspektīvai, ir saistīti ar policijas un politikas savstarpējo iedarbību, kā arī policijas funkciju un lomas dažādošanu.

Pētỉjumi var aptvert l̦oti plašu lomu spektru, ko policija ieņem kā noziegumu novērsēji, kā pakalpojumu sniedzēji, kā kārtības nodrošinātāji un nekārtību un domstarpỉbu novērsēji. 
Policijas aktivitāšu stratēgijas un stili ir kḷuvuši par svarīgu policijas pētijumu sastāvdaḷu. Kriminālizmeklēšanas process, policijas darbības modelis, kas pielāgots kopienu interesēm, ASV zinātnieka Hermaṇa Goldsteina (Herman Goldstein) uz problēmām orientētais policijas darba stils [9] un policijas darbỉba, balstìta uz slepeno informāciju - tie ir dažādie stili, kas zināmi un par ko tiek diskutēts daudzās Eiropas valstīs. Ielūkojoties policijas pētījumos, kas skar pašu policijas organizāciju, tad daudz tiek diskutēts par vadības problēmām un policijas darba kultūru.

\section{Policijas zinātnes jēdziena raksturojums}

Kas ir zinātne? Zinātne ir pētnieciskās darbības sfēra, kuras mērḳis ir jaunu zināšanu radīšana un sistēmiska sakārtošana. [8]

Vai policijas zinātne ir fundamentāla vai lietiškła? Policijas zinātne veic zinātniskus pētỉjumus par policiju kā institūciju un policijas darbību kā procesu. [6] Kā lietišḳa zinātne tā apvieno radniecīgas zinātniskās izziņas metodes un subjektus policijas aktivitāšu jomā, ieskaitot to, ko policija dara, kā arī ietekmi no ārpuses, kas atstāj iespaidu uz sabiedrisko kārtību un policijas darbību. Policijas zinātne ir pētnieciskās darbības sfēra, kuras mērkis ir jaunu zināšanu radīšana un sistēmiskā sakārtošana, kas attiecas uz policijas darbības realitāti. Policijas zinātne atrodas grūti risināmu jautājumu viduspunktā un skar pētỉjumu, apmācību, izglìtỉbas, pilnveides un inovāciju būtību. Tā nav zinātne pati ar saviem likumiem, tā apvieno radniecīgas zinātniskās izziṇas metodes, piemēram, sociālo zinātṇu, kriminolog̣ijas un kriminālistikas.

Kā lietišķa zinātne tā uzrunā policijas pētỉjumus veicošo akadēmisko pasauli, kā arī policijas darbiniekus, kas iesaistīti apmācībā, izglìtībā, pētniecībā un problēmu atrisināšanā, meklējot zinātnē balstītus risinājumus.

Pirmkārt, policijas zinātne tās plašā izpratnē un vispārējā nozīmē - kā dažādu zinātṇu nozaru izmantošanas iespēja, lai sekmētu policijai izvirzìto mērḳu sasniegšanu, piemēram, policijas tiesību, kriminālistikas, kriminolog̣ijas un citu zinātṇu nozaru izmantošanas iespēju pētǐšana.

Otrkārt, policijas zinātne tās šaurā nozīmē koncentrējas uz policiju kā institūciju un tās darbību sabiedrības kontroles jomā.

Var izdarìt secinājumu, ka dotajā policijas zinātnes jēdziena pirmajā nozīmē tiek runāts par dažādu zinātṇu nozaru pētijumu rezultātu izmantošanu policijā (profesionālismu un specializāciju). Otrā gadījumā policijas zinātne tiek orientēta uz policiju kā institūciju tās organizācijas un darbības attīstību uz zinātnes pamatiem.

Ar "policiju" mēs saprotam valsts institūciju (vai institūcijas), kas ar nelielām atš̌kirībām pazīstama visās Eiropas valstīs. [2] Pretēji tai "policijas darbība" ir process: termins, ko varam piemērot sabiedrības drošības un sabiedriskās kārtības nodrošināšanai [4], noziedzības novēršanai un atklāšanai, reageējot uz izsaukumiem un saistībā ar noziedzīgā nodarījumā cietušajiem. Bez policijas te var būt iesaistītas bezpel̦nas organizācijas, piemēram, nevalstiskas organizācijas vai arī pelnošas organizācijas privātā sektorā. Tātad te ir runa par policijas darbību jaukta tipa aktivitātēs, kurās piedalās arī citas 
organizācijas. Lai gan policijas darbības pasūtītājs ir valsts, tradicionālā Valsts policija tagad ir atbildīga tikai par dal̦ēju policijas pakalpojumu sniegšanu daudzās Eiropas valstīs. Pārējo nodrošina privātais sektors, citas valsts sektora institūcijas. To varētu nosaukt par policijas darbības mūsdienu "daudzpusību", un viens no policijas zinātnes būtiskākiem jautājumiem būtu izpētīt šìs paplašinātās policijas darbības izpratnes nozīmi.

Turpmākā pētījumu attīstība nevar aprobežoties ar policiju kā institūciju, zinātniskie pētỉjumi par drošību un policijas darbību paplašināsies, veidojot vispārīgāku izpētes līmeni.

\section{Eiropas pieeja policijas zinātnei}

Galvenais mērḳis Eiropas pieejā policijas zinātnei ir policijas institūciju, policijas filozofiju, darba procesu un viedokḷu par problēmām salīdzināšana. Salīdzināšanas nolūks policijas darbības jomā ir iegūt informāciju par līdzīgiem jautājumiem un problēmām ārzemēs, samērojot savus sasniegumus ar citu veikumu, panākt labāku izpratni citam par citu Eiropā, labāk saprast pašiem savas aktivitātes. [10]

Salīdzinošā pieeja (lai arī bieži tikai kā papildu aspekts) sakārto pieredzes un informācijas apmaiṇu sistemātiskā veidā, dodot iespēju mācīties citam no cita. Tas ir nopietns solis cẹ̦ā uz Eiropas identitāti, laujot zināt, kas notiek, kāpēc notiek un kādi bùtu alternatīvie celii, lai to paveiktu.

Policijas zinātne ir lietišḳā zinātne, un tā seko citu zinātṇu salīdzinošām perspektīvām un metodologiskajiem standartiem.

Metodologija ietver divas pieejas: skatoties no augšas uz leju - tā ir tuvāka sociālo zinātṇu metodologijai. Skatoties no reālas policijas darbības, tā rada metodes atbilstoši problēmām. Un pretēji: pirmās ir problēmas un pētnieciskā darba jautājumi un tad, kā otrais solis, tiks izvēlēta un attīstìta piemērota metodologiskā pieeja.

Mūsdienās policijas darbs nav autonoma, neatkarīga profesija. Tas lielā mērā ir atkarīgs no sabiedrības attīstības, politikas un noziedzīgajām struktūrām. Mainīgās noziedzīgās struktūras prasa izmaiṇas policijas darbībā un piemērotu instrumentu izvēlē - policijas darbā izmaiṇas ir jāuztver kā normāla parādība.

Sastopoties ar pašreizējām nacionālās un starptautiskās policijas pētniecības, izglìtības un apmācības aktivitātēm, var apgalvot, ka daudzas no tām ir atsevišḳas problēmas, ko nosaka praktiskās vajadzības, bet vispārīgie jautājumi policijas kultūrā tiek lielākā vai mazākā mērā atstāti bez ievērības. Varētu būt, ka tas ir saistìts ar zinātniski pētniecisko darba un apmācību kultūru, kuru nosaka praktiskā un empīriskā dominēšana un bailes no "teorijas".

Tiklīdz pētnieks kādā policijas institūcijā tiek turēts aizdomās, ka viṇš rada "teoriju" "praktisku zināšanu" vietā, viņš ātri vien tiek izslēgts no spēles. Bet policijas zinātnei ir nepieciešama "teorija" ne tikai piemērotu metodoloğisko aspektu dēl, bet arī diskusijām par galvenajiem jautājumiem.

Viens no svarīgākajiem uzdevumiem nākotnē ir aptvert galvenos aspektus policijas darbībā, novērojot, analizējot, aprakstot un dodot ieguldījumu specifiskās pētniecības un mācību aktivitātēs. 
Otrs aspekts ir turpināt apspriešanu un iekḷaut Eiropas policijas zinātnes attīstības vēsturi pētniecības darba un mācību aktivitātēs. Šis varētu būt arī Eiropas identitātes elements zinātniski pētniecisko un mācību aktivitāšu jomā.

Pievēršot uzmanību pārrobežu perspektīvai, jāsāk ar salīdzinošo aspektu. Eiropas valstīs trūka salīdzinošo pētījumu.

Nepieciešami salīdzinošie pētījumi par šādām jomām: policijas sistēmas, policijas filozofijas, policijas vēsture, policijas darba stili, policijas kultūra utt., un tas ir svarīgs uzdevums saistībā ar nākotnes perspektīvām.

Jāsecina, ka policijas zinātne vēl nav sasniegusi citu radniecīgu zinātṇu līmeni, piemēram, politolog̣ijas līmeni, kur politisko sistēmu salīdzināšanai ir ierādīta centrālā vieta.

Tā ir atslēga, lai izprastu un izskaidrotu, kas notiek Eiropā policijas darbības jomā. Citiem vārdiem sakot, par šìm jomām nav izpratnes bez salīdzinošas izpētes.

Valstu ietvaros policijas darbïbas koncepcijas un to pielietojumu praksē var apgūt, valstīm salīdzinot savas sistēmas un darba rezultātus. Darbības vērtējuma kritēriji ieviešami praksē Eiropas policijas darbības jomā. Līdz šim nav atrasta sistemātiska pieeja, kā to paveikt. Vēl vairāk, papildu ceḷi informācijas vākšanai būtu pārveidojami sistemātiskā pieejā, lai iegūtu un izplatītu zināšanas, kas balstās uz zinātniski pētnieciskā darba rezultātiem. Pat atsevišḳu problēmu jautājumu salīdzinošie pētỉjumi varētu būt solis pretī efektīva izvērtējuma izstrādei, pat ja netiktu lietots šis termins.

Papildu dimensija policijas zinātnē ir tā, kas vairāk sakṇojas politikā, nevis teorijā. Apskatot jautājumu, kā policijas darbība saplūst un apvienojas dažādās Eiropas valstīs, var apsvērt, cik lielā mērā attīstība vienā ir bijusi veiksmīgāka nekā citās. Te viens no aspektiem ir policijas darbības efektivitātes izvērtēšana. [5]

\section{Policijas izglīīiba un policijas apmācība}

Boloṇas procesam ir dziḷa ietekme uz universitāšu/augstāko mācību iestāžu sistēmu Eiropā. Eiropas Savienības dalībvalstīs policijas apmācības un izglìīibas sistēma mainās, virzoties pretī Boloṇas procesa rekomendāciju pien̦emšanai. [11]

Policijā domas dalās par attieksmi pret turpmākās policijas izglìīibas attīstības risinājumiem. [7]

Policijas apmācība ietver procesu, kurā iegūst zināšanas, apgūst prasmes un iemaṇas, lai varētu veikt specifiskus profesionālos uzdevumus.

Policijas izglīiības mērḳis arī ir zināšanas, prasmes un domāšanas veids, bet to māca, vairāk attīstot domāšanu, izpratni, tas ir vairāk vērsts uz problēmu risināšanu un analīzi.

Policijas zinātne piedāvā palīdzību gan policijas izglìtỉbai, gan policijas apmācībai. Saturs (policijas izglīīibas temati), metodologija (pētijumi un problēmu risināšanas metodes) un intelektuāla attīstība (kritiskā domāšana) ir sastāvdal̦as saiknei starp policijas izglïtību un policijas zinātni. Tas viss veicina un attīsta studentu spējas vispārināt, saskatìt attiecības un efektīvi darboties jaunās situācijās, ko pilnībā nevar vizualizēt vai definēt. 
Policijas apmācība vairāk balstās uz praktisko pieredzi un praktiskām iemaṇām, tomēr tā nebūtu jānoškị no policijas zinātnes.

Mūsdienu sabiedrībā, kas balstīta uz zināšanām, praktiskās iemaṇas un prasmes var pamatot uz zināšanām, kas iegūtas no zinātnes un pētỉjumu rezultātiem, lai gan tās mērḳis nav radìt zinātniskus cel̦us problēmu risināšanai.

Policijas apmācību un izglītības sistēmas Eiropas Savienības dalībvalstīs parāda nepieciešamību sadarboties praktiskā darba veicējiem ar akadēmisko personālu, policijas darbiniekiem - ar pētniekiem.

Policijas zinātnes rezultātu îstenošana policijas praksē ir liels nākotnes izaicinājums.

Daži uzskata, ka būtu jānoškirir policijas apmācība no policijas izglītības, sakot, ka policijas pētnieciskais darbs var brīvi attīstīties tikai tad, ja to veic zinātniski pētnieciskajos institūtos neatkarīgi no policijas. Citi aizstāv viedokli, ka jāintegrē policijas apmācība un izglītība, pārveidojot Eiropas Savienības nacionālās policijas akadēmijas par akreditētiem akadēmiskiem institūtiem augstskolu (universitāšu) sistēmā, tādā veidā padarot pozitīvo ietekmi, ko policijas pētījumi un augstākā izglīiība atstāj uz policijas organizāciju, iespējami lielāku.

Boloṇas process nodrošina šīs attīstības vispārīgo struktūru, kurā par akreditāciju ir atbildīgas nacionālas akreditācijas institūcijas.

Otra pieeja, kas ir sakritīga ar iepriekšminēto, ir izveidot Eiropas mēroga kopējas studiju programmas vadlīnijas policijas apmācībām un izglìtībai. [1]

\section{Development of Police Science in Europe}

\section{Abstract}

Development of police science in Europe and related research results are presented in the published materials. Studies have been published presenting different opinions, but the majority view is that Europe should develop a police science as a separate branch of science.

The study aims to look at the development of police science in Europe, which could serve as the beginning of scientific debate on this issue.

Police science might be an instrument of integration, both nationally and internationally in the future. The perspectives of its development in Europe are dependent on both the academic and community policing activities.

Keywords: police, police science, police activity. 


\section{Literatūra}

1. Garonskis, A. Eiropas policijas akadēmijas loma mūsdienu policijas darbinieku izglītošanā. Starptautiskās zinātniski praktiskās konferences "Policijas augstākās izglītības vadības problēmas" materiāli. LPA, 2007, 11.-20. lpp.

2. Indrikovs, Z. Policijas jēdziens demokrātiskā valstī. Administratìvā un Kriminālā Justīcija, Nr. 3, 2007, 13.-21. lpp.

3. Matvejevs, A. Policijas institūta un policijas tiesību zinātnes veidošanās sākumi. Administratīvā un Kriminālā Justīcija, Nr. 1, 2007, 25.-32. lpp.

4. Matvejevs, A. Sabiedriskās kārtības un sabiedrības drošības jēdzienu definējums un analīze. Administratìvā un Kriminālā Justīcija, Nr. 2, 2007, 35.-46. lpp.

5. Matvejevs, A. Valsts policijas darbības efektivitātes vērtēšanas tiesiskie kritēriji. Administratīvā un Kriminālā Justìcija, Nr. 3, 2005, 60.-66. lpp.

6. Matvejevs, A. Policijas zinātnes attīstības daži aspekti. Administratīvā un Kriminālā Justīcija, Nr. 2, 2004, 35.-38. lpp.

7. Smits, S., Emodts, M. Saistība starp izglītību, pieredzi un policijas darba izpildi. Administratīvā un Kriminālā Justìcija, Nr. 2, 1999, 50.-53. lpp.

8. Vedins, I. Zinātne un patiesība. Rìga: Avots, 2008, 15. lpp.

9. Goldstein, H. Improving policing: A problem-oriented approach. Crime E Delinqency, Nr. 25, 1979, p. 236-258.

10. Perspectives of police science in Europe. Final Report, European Police College, April, 2007, [sk. 2015. g. 26. janv.] Iegūts no: www.cepol.europa.eu/

11. Schindler, T. Die polizei auf dem weg nach Bologna. Journal, Zeitschrift Für Polizeiwissenhaft und Polizeiliche Praxis. Respublik Österreich, Nr. 2, 2007, p. 25-40. 